\title{
Characteristics of Supersonic Closed Loop with Disk CCMHD Generator
}

\author{
Hiroyuki Yamasaki Member (Tokyo Institute of Technology) \\ Tomoyuki Murakami Member (Tokyo Institute of Technology) \\ Yoshihiro Okuno Member (Tokyo Institute of Technology)
}

Keywords: supersonic closed loop, disk MHD generator, high temperature argon circulation, energy balance, pressure ratio

Results of experimental study on performance of a supersonic closed loop with a disk MHD generator are described. The experiment was carried out using the closed loop shown in Fig. 1. The closed loop consists of a high temperature argon heater, a disk MHD generator, a recuperator a cooler, a molecular impurity removal system and a compressor. A series of experiment to heat argon up to high temperature ( $>1900 \mathrm{~K}$ ) had been carried out. As a result, the high temperature argon circulation during 2.4 hours was demonstrated. Time trace of argon temperature is shown in Fig. 2. It is noted that the highest argon temperature of $1974 \mathrm{~K}$ is obtained during time period from 47.1 hours to 47.8 hours.

The heat gain and loss of argon circulating inside the closed loop is also our concern. Argon temperature distribution along the flow direction and the heat loss at each component were measured. A large heat loss was found at the diffuser and the exhausting duct although the energy efficiency of recuperator was high. The large heat loss was ascribed to water cooling at the diffuser and the exhausting duct. Furthermore, a significant enhancement of heat transfer coefficient in these ducts was suggested. The argon temperature calculated under an assumption of four times larger heat transfer coefficient agrees well with experimental one, and it is shown in Fig. 3. At the same time, the calculated heat loss was close to the measured one. The enhanced heat transfer coefficient could be explained by a complex flow field inside the ducts.

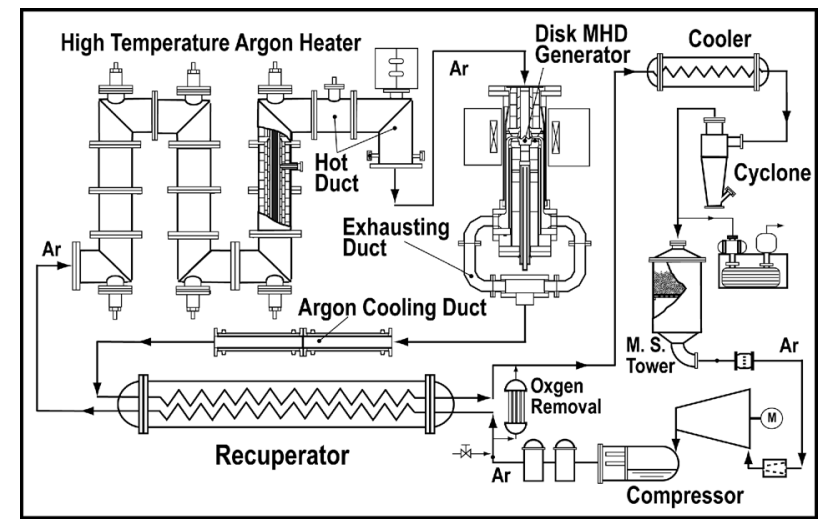

Fig. 1. Schematic diagram of supersonic closed loop with disk MHD generator

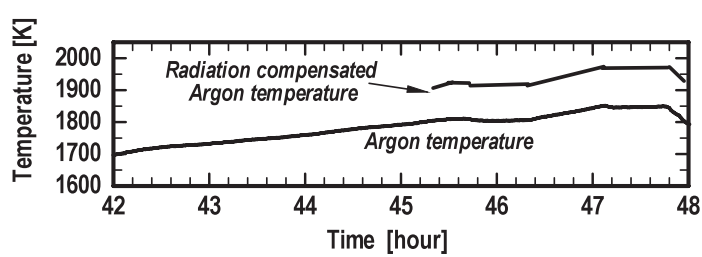

Fig. 2. Time traces of argon temperature, pressure and flow rate
A remarkable reduction of throat height at the supersonic nozzle inside the disk MHD generator was found for the first time, and this was due to thermal expansion of an inlet duct located upstream the nozzle. This suggests that a special attention should be paid to a design of this part because the throat height in the disk MHD generator is usually small.

The pressure ratio inside the loop was also discussed. The result has indicated that the total pressure at the upstream of throat is decided by the total temperature and the mass flow, because the flow is choked at the throat in the supersonic closed loop. On the other hand, the total pressure at the downstream of throat is determined by the total mass in the loop and the total pressure at the upstream. The determined total pressure at the upstream and the downstream have shown a good agreement with measured ones.

Contamination of argon by water, oxygen and nitrogen affects performances of MHD generator. Therefore, their concentrations should be kept as low as possible. In the present experiment, concentrations of water, oxygen and nitrogen were reduced with an increase of argon temperature, and they were kept less than $40 \mathrm{ppm}$, $20 \mathrm{ppm}$ and $150 \mathrm{ppm}$, respectively. Therefore, the first power generation was carried out, and a good correlation between the load resistance and the Hall voltage was observed as shown in Fig. 4. However, a power output remained very small.

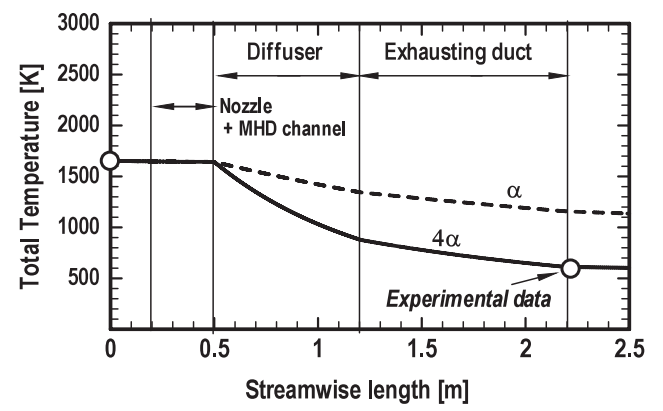

Fig. 3. Comparison of measured and calculated argon temperature for different heat transfer coefficient

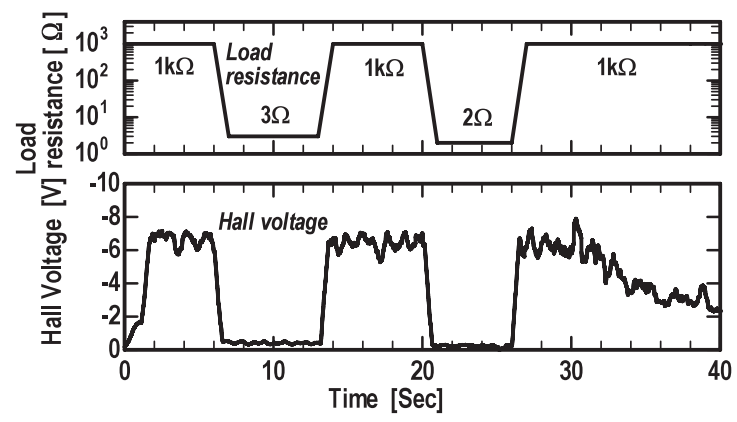

Fig. 4. Time traces of load resistance and Hall voltage 


\title{
ディスク形CCMHD発電機を組込んだ 超音速クローズドループの特性
}

\author{
正 山岬 裕之* 正員 村上 朝之* \\ 正 員 奥野 喜裕*
}

\section{Characteristics of Supersonic Closed Loop with Disk CCMHD Generator}

Hiroyuki Yamasaki*, Member, Tomoyuki Murakami*, Member, Yoshihiro Okuno*, Member

\begin{abstract}
Results of experimental study on performance of the supersonic closed loop with a disk MHD generator are described. The high temperature (>1900 K) argon circulation was carried out successfully during 2.4 hours. The heat gain and loss of argon was investigated, and a large heat loss was found at the diffuser and the exhausting duct although an energy efficiency of recuperator was high. The large heat loss was ascribed to water cooling at the diffuser and the exhausting duct. At the same time, the enhancement of heat transfer coefficient was suggested. The argon temperature and the heat loss calculated under an assumption of four times larger heat transfer coefficient have shown a good agreement with experimental ones. The pressure ratio inside the loop was discussed, and the result has indicated that the total pressure at the upstream of nozzle throat is decided by the total temperature and the mass flow. On the other hand, the total pressure at the downstream is determined by the total mass in the loop and the total pressure at the upstream. The first power generation was carried out, and a good correlation between the load resistance and the Hall voltage was observed. However, the power output remained very small.
\end{abstract}

キーワード：超音速クローズドループ, ディスク形 MHD 発電機, 高温アルゴン循環, エネルギーバランス, 圧力比

Keywords: supersonic closed loop, disk MHD generator, high temperature argon circulation, energy balance, pressure ratio

\section{1. はじめに}

希ガスを作動気体とするクローズドサイクル (Closed Cycle) MHD 発電（以下, CCMHD 発電と略記) については, 高いエンタルピー抽出率の実証と等エントロピー効率の飛 躍的な向上が実験的に示され(1)，また発電システムについ ても幾つかの提案がなされてきた。Fig. 1 には，天然ガス と組合せた CCMHD 単独発電システムの構成を示したが, このシステムは左側の燃焼系と右側のクローズドループに 大別される。右側のクローズドループは, 高温熱交換器に よる希ガスの加熱, 発電, 発電機からの排ガスの熱回収, 冷 却，希ガスの圧縮の役割を担っており，この発電プラント の構成要素として重要な部分である。この単独サイクルの システムは最も単純であり，また総合熱効率として最も高

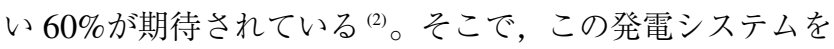
将来実現するためには, クローズドループの特性について

\footnotetext{
* 東京工業大学大学院総合理学研究科創造エネルギー専攻

干 266-8502 横浜市緑区長津田町 4259

Department of Energy Sciences, Interdisciplinary Graduate School of Sciences and Engineering, Tokyo Institute of Technology

4259, Nagatuta, Midori-ku, Yokohama 226-8502
}

の知見が求められている。

クローズドループを用いたこれまでの研究例としては, 1963-1970 年頃に旧西ドイツの原子力研究機関で ARGAS と呼ばれる大型の装置で行った実験がある(3)。また，19681976 年頃に米国の NASA-Lewis 研究センターで行った実 験例もある(4)。これらの研究例ではいずれもリニアーのファ

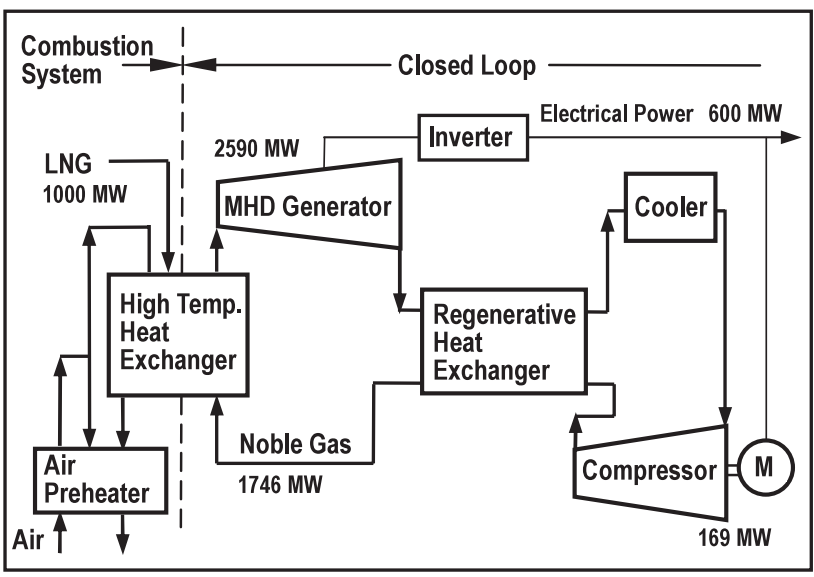

Fig. 1. Closed loop in CCMHD single cycle power plant system combined with natural gas ${ }^{(2)}$. 
ラデー形 MHD 発電機を用い，発電機内の流れが覀音速と なるクローズドループを設置して実験を行った。その実験 の主目的は, 当時一番大きな課題とされていた非平衡電離 が実現するかどうかを調べるとともに，小さな出力ではあ るものの，発電を実証することであった。これらの先駆的 な実験の後, CCMHD 発電の研究は, ミリ秒の実験が可能 な衝撃波管装置や 60 秒程度の実験が可能なブローダウン 装置を用いた実験へと移行した。その結果，MHD 発電機 内で超音速流れを用いた場合には，非平衡電離が著しく促 進されることが示されるとともに，上で述べたように，高 いエンタルピー抽出率の実証と等エントロピー効率の飛躍 的な向上が示された。

このような研究背景の下に，再びクローズドループに関 心が向けられ，筆者らは熱入力の小さな小型の超音速クロー ズドループの概念設計を行うとともに，その性能を一次元 の数值シミュレーションにより調ベ, ループの流体的, 熱的 な特性や発電特性について明らかにした ${ }^{(5)}$ 。また 2002 年度 末に，小型の超音速クローズドループが東京工業大学に設 置され，2003 年度から実験が開始された。同時に，数值シ ミュレーションも行われ，クローズドループの定格運転時 におけるエネルギーおよび圧力バランスの予測がなされる とともに，ループの立上時の運転手法の提案がなされた ${ }^{(6)}$ 。

このクローズドループでは, 従来のループとは異なり超 音速流れを用いていること，またディスク形 MHD 発電機 が組込まれていることに大きな特色がある。本論文ではこ の超音速クローズドループを研究対象とし，ループの熱的. 流体的特性を実験的に明らかにするとともに，発電実験の 結果について述べ，将来の超音速クローズドループの構築
に資することを目的としている。

\section{2. 実験装置および実験条件}

$\langle\mathbf{2} \cdot \mathbf{1}\rangle$ 実験装置 本研究では, Fig. 2 に示すような超 音速クローズドループを用いた。このループは，「高温アル ゴンヒータ」,「ディスク形MHD 発電機」,「超伝導磁石」,「排 気ダクト」,「アルゴン冷却ダクト」, 「再生熱交換器」,「クー ラ」,「サイクロン」，「モレキュラーシーブ（M.S.）塔」，「圧 縮機」などの主要コンポーネントで構成されている。Fig. 2 と Fig. 1 のクローズドループと比較すると，本装置には将 来のプラントで必要とされる多くのコンポーネントが組込 まれていることが分かる。その一方, 蓄熱型の高温熱交換 器が, 本装置では電気加熱式の「高温アルゴンヒータ」に置 換えられている。将来の発電プラントでは，蓄熱型の高温 熱交換器によりアルゴンが加熱されるが，この場合には蓄 熱体の燃焼ガスによる加熱, 燃焼ガスの真空排気, アルゴ ン加熱というプロセスが必要であり，連続運転のためには 複数台の蓄熱型熱交換器を必要とし，またそれらの切替え という煩雑さが生じる。そこで，この煩雑さを避けるため 本装置では発熱体として多数のタングステンエレメントを 組込んだ電気ヒータを用いた。さらに，将来のプラントで のセラミックを蓄熱体とする再生熱交換器の代わりに，金 属製の隔壁型再生熱交換器（Recuperator）を用いている。 なお，本装置の各コンポーネントの詳細は既報(6)(7) で述べ たのでここでは省略する。

〈2·2〉 ループ内のアルゴンの循環と運転制御＼cjkstart次に， Fig. 2 でのループ内を循環するアルゴンの流れについて説 明する。アルゴンは，オイル冷却式のスクリュー型圧縮機

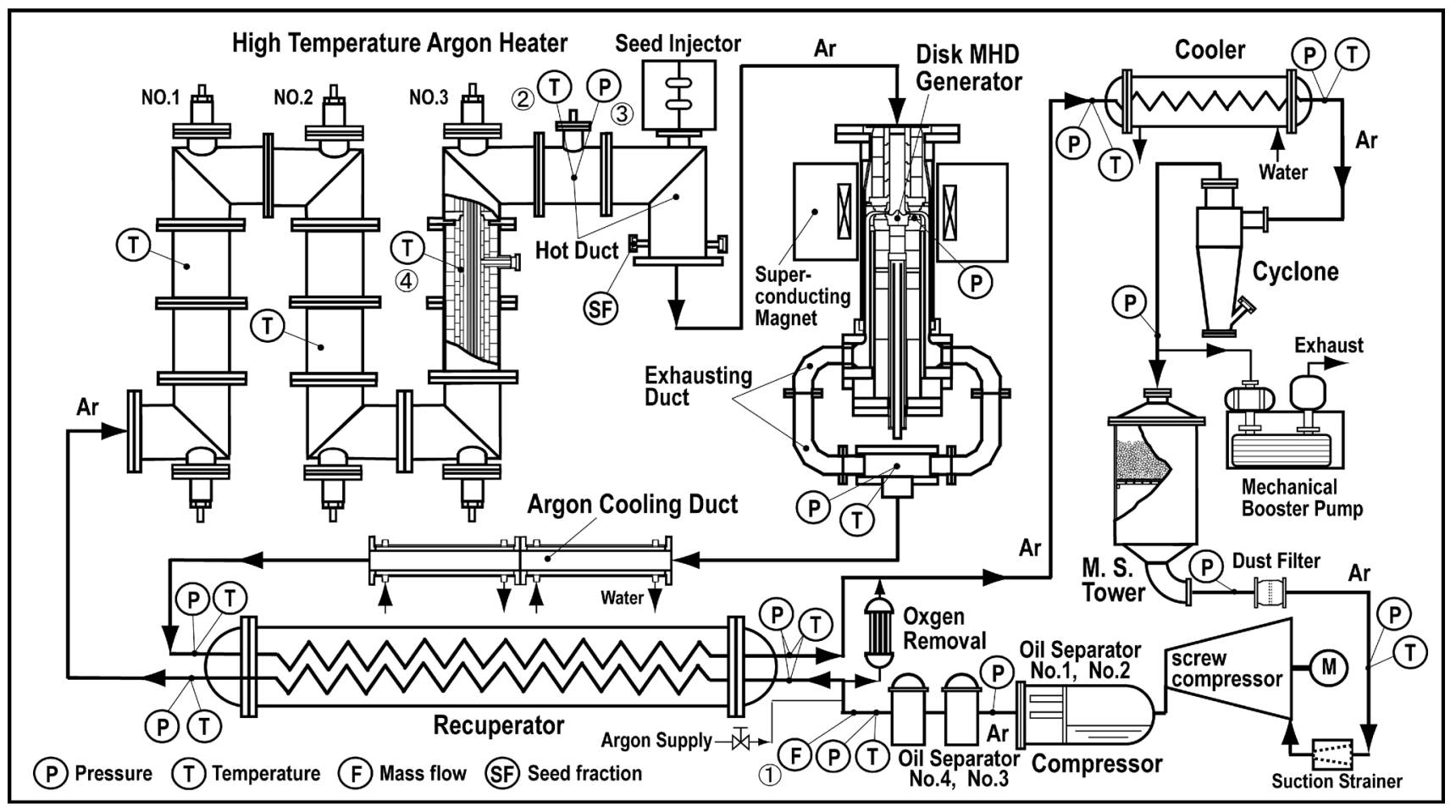

Fig. 2. Schematic diagram of supersonic closed loop. 
で所定の圧力まで加圧され，その後オイルセパレータ No.1 から No.4 までを通過し，オイルミスが重量比で 1 ppm 以 下にまで除去されて吐出される。この加圧アルゴンは, 再 生熱交換器内に設置された 202 本の二重円環内の外側環状 流路を通過し，内側の円管内を流れる高温のアルゴンと熱 交換を行い加熱される。この予備加熱されたアルゴンは, No.1 から No.3 までの 3 台で構成される高温アルゴンヒー 夕に導かれ，順次加熱される。その後，高温のアルゴンは ホットダクトを通りディスク形MHD 発電機へと導かれる。

ディスク形 MHD 発電機の下流には 6 本の排気ダクトが 設けられており，ここを通過したアルゴンはさらに水冷式 のアルゴンクーリングダクトで冷却され, 再生熱交換器で 圧縮機からのアルゴンに熱を受け渡し，自らは冷却される。 さらに，冷却されたアルゴンはクーラにより水温近くまで 冷却され，サイクロンでダストが除去された後モレキュラー シーブ (M.S.) 塔に流入する。モレキュラーシーブ塔では, アルゴン中に含まれる水分がゼオライトの吸着剤により除 去される。またその下流のダストフィルターでは，サイク ロンでは除去できなかったアルゴン中の微細なダストが取 除かれる。その後，アルゴンは圧縮機入口に設けられた吸 入フィルターでさらに細かいダストが除去され, スクリュー 型圧縮機に流入して一回の循環を終了する。

次に, 本ループの運転制御について述べる。運転中は, ア ルゴン流量（Fig.2の１）を監視しつつ，圧縮機の吐出流量 の制御を手動もしくは自動で行った。また，後で述べるよ うにディスク形 MHD 発電機のスロート高さが時間的に減 少してホットダクト内の圧力が高くなる場合には，圧縮機 の流量を下げて，その圧力を規定值（=0.55 MPa）以下に 抑えるように運転した。

$\langle\mathbf{2} \cdot \mathbf{3}\rangle$ 実験経過と試験項目 本研究ではRun 1 から Run 15 までの 15 回の試験を行ってきた。Run 1 から Run 7 では，超音速クローズドループの運転手法を確立すること を主な目的とした。また Run 8 から Run 12 では, 高温アル ゴンヒータへの投入電力を徐々に増加させてアルゴン温度 の向上を図った。さらに，高温アルゴンヒータとその下流 のホットダクト (Fig. 2 の上, 中央左側参照), さらにディ スク形 MHD 発電機で用いられているセラミックから放出 される水分の除去に努めた。また，Run 12 ではクローズ ドループの温度がほぼ定常になるまで長時間運転し，流れ 方向の圧力分布や温度分布，さらにエネルギーバランスに ついて調べた。Run 13 から Run 14 では，より高い温度の アルゴンを循環させることを目標としたが，ダストフィル ターや圧縮機出口のオイルフィルターの目詰まりが生じ, 圧縮機の吐出圧力が異常に高くなる現象が見られた。しか し, Run 14 ではセシウムシードの注入に初めて成功した。 そこで, Run 15 ではフィルターの目詰まりの対策を施し, また超伝導磁石を印加して発電実験を試みた。

\section{3. 実験結果と検討}

〈3・1〉 アルゴンの加熱特性とその温度分布 高温度

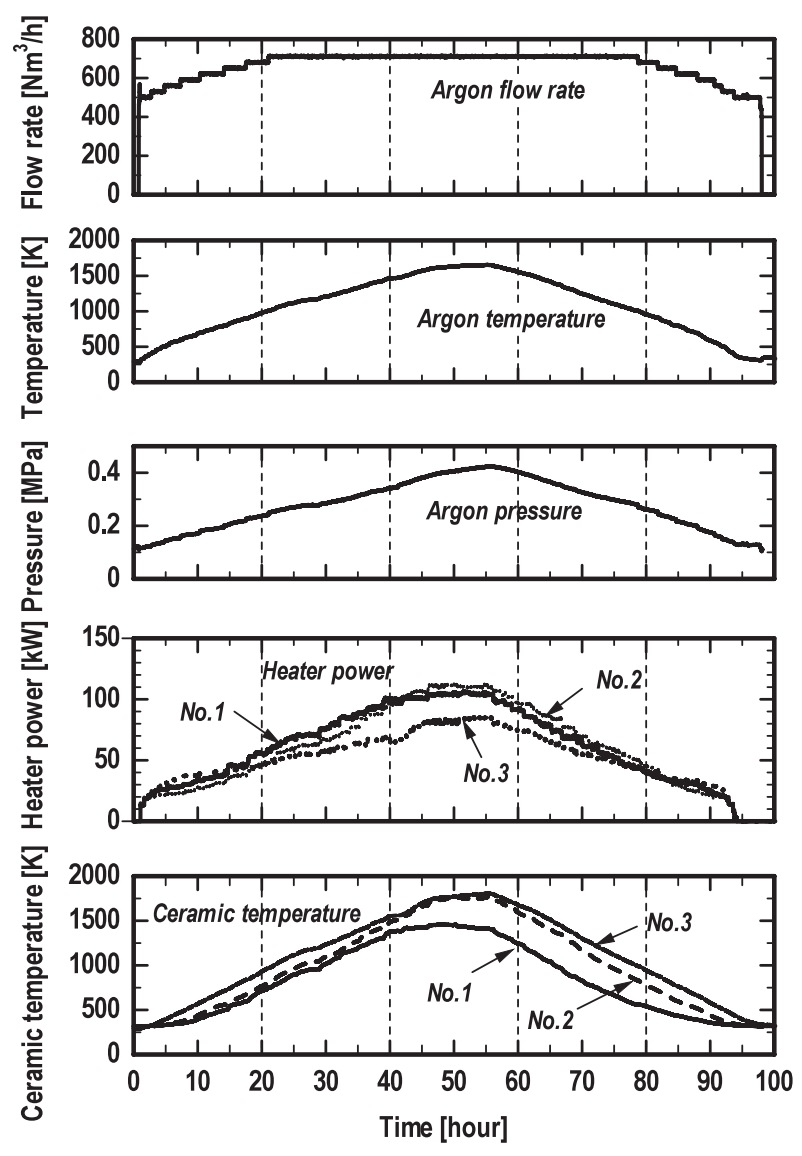

Fig. 3. Time traces of argon flow rate, argon temperature, argon pressure, heater power and ceramic temperature in Run 12.

で動作するクローズドループ内のアルゴンの温度やエネル ギーバランスのデータは，将来の高効率発電プラントを実 現するためにも重要であり，本実験での大きな関心事の一 つである。エネルギーバランスを知るためには，ループ内 の流路の壁温が時間的にほぼ一定となる条件を実現する必 要がある。もし, 壁温が非定常的に変化している場合には, 壁の熱容量が影響し，エネルギーバランスが成立しない。 そこで，ここではアルゴン温度を高く保った状態を約 8 時 間維持して，ほぼ定常な状態を実現したRun 12 での結果 について述べる。

Fig. 3 には, アルゴン流量 (Fig. 2 の(1)計測位置) とホッ トダクトで計測したアルゴンの温度（Fig.2の（2）と圧力 (Fig. 2 の(3)，および高温アルゴンヒータへの投入電力と セラミック壁温（Fig.2 の(4)）の経時変化を示した。この 図では，アルゴン流量は圧縮機の起動（=時刻 0) の直後 に $500 \mathrm{Nm}^{3} / \mathrm{h}(=0.247 \mathrm{~kg} / \mathrm{s})$ となり，その後は段階的に増 加し, 約 21 時間後に定格流量の $710 \mathrm{Nm}^{3} / \mathrm{h}$ になっている。 また，この流量は時刻 78 時間まで維持されている。次に 高温アルゴンヒータへの投入電力に着目すると，これにつ いても実験時間内で徐々に変化せていることが分かる。ま た投入電力の増加に伴いアルゴン温度（流速が低いためほ ぼ全温に等しい) も上昇し，アルゴンヒータNo.3の投入 


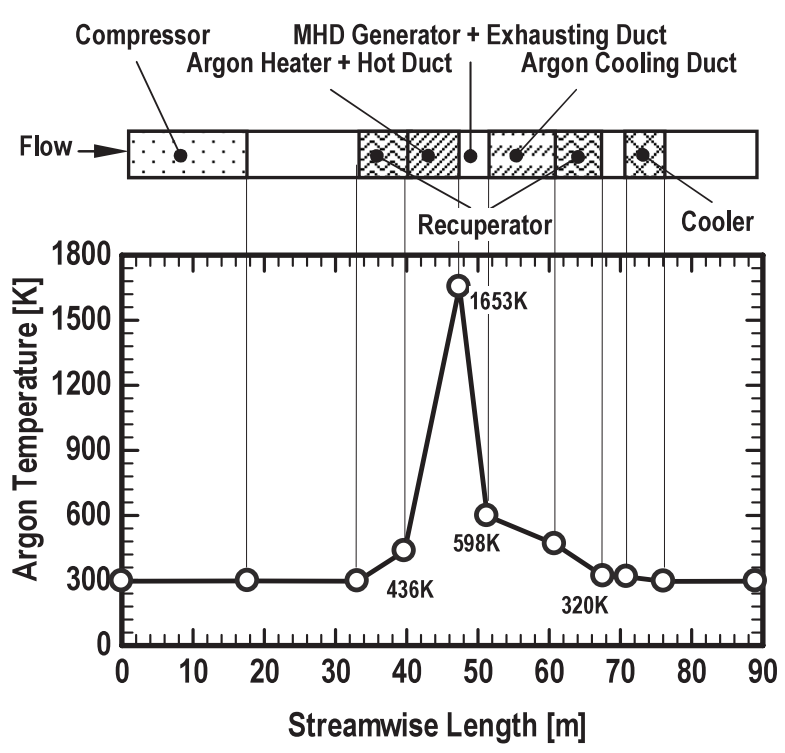

Fig. 4. Argon temperature distribution along flow direction in Run 12.

電力が最大となっている 46-56 時間で， $1650 \mathrm{~K}$ のアルゴ ン温度が得られていることが分かる。このようにアルゴン の加熱には長時間を要しているが，この長時間を有する加 熱は, 高温度で動作するクローズドループに固有のもので ある。将来の発電プラントを考えた場合, ループの高温部 分の機器には耐熱性からセラミックが使用されるが，その 際熱応力による破損を避けるためにセラミックの温度変化 率には上限があり，本実験では $40^{\circ} / \mathrm{h}$ 以下に抑えた。この ような温度変化率の制約は, 発電プラントの立ち上げや停 止に長時間を要することを示しており,さらに負荷変動に よって希ガスの温度が急激に変化することは, 極力避けな ければならないことを示唆している。

次に, Fig. 3 のアルゴンの圧力の時間変化を見ると, ア ルゴン流量が一定となる 21 時間からは, アルゴン温度の 上昇に伴い圧力も上昇している。これは，後で述べるよう に超音速ノズルを持つクローズドループでは，流量が一定 の場合，ノズルのスロートよりも上流の圧力はアルゴンの 温度で決定されることを示している。

Fig. 4 には，この実験で最高の $1650 \mathrm{~K}$ のアルゴン温度が 得られた時のループ内のアルゴン温度（ほぼ全温に等しい） の分布をプロットした。この図より，圧縮機を出た室温程 度のアルゴンは, 再生熱交換器に流入して予備加熱され, その出口では $436 \mathrm{~K}$ まで加熱されていることが分かる。ま た，予備加熱されたアルゴンは高温アルゴンヒータでさら に加熱され，その温度は $1653 \mathrm{~K}$ となっている。その後，ア ルゴン温度はディスク形発電機とその下流の排気ダクトで 大幅に低下し，排気ダクト出口で $598 \mathrm{~K}$ となっている。ま た，排気ダクトを出たアルゴンはアルゴンクーリングダク 卜で冷却され，さらに再生熱交換器で圧縮機から流入する アルゴンに熱を受け渡してその温度が下がり，再生熱交換 器出口での温度は $320 \mathrm{~K}$ となっている。その後アルゴンは, クーラで $296 \mathrm{~K}$ まで泠却され，サイクロンとモレキュラー

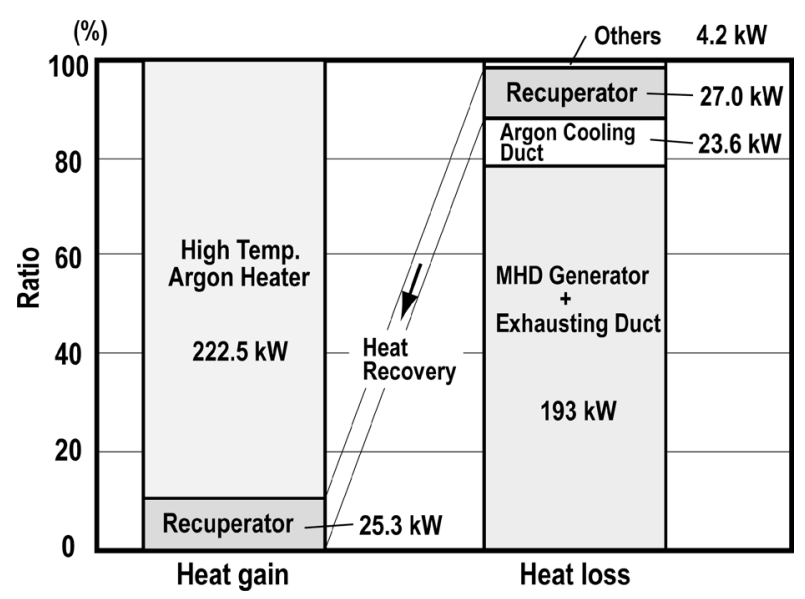

Fig. 5. Experimental result of heat gain and loss of argon in Run 12.

シーブ塔を経由して圧縮機に戻っている。

〈3・2〉 アルゴンの熱の授受とエネルギーバランス 上 で示したように, 本研究ではループの各部のアルゴンの温 度を知ることができたが，この温度のデータとアルゴン流 量から，アルゴンが得た熱量や失った熱量を見積もること ができる。その結果を, Fig. 5 に示した。Fig. 5 の左側の棒 グラフは, アルゴンが得た熱量を示しているが,ここではそ れを再生熱交換器から得た熱量と高温アルゴンヒータから 得た熱量の和としている。Fig. 1 に示すサイクルでは, 圧縮 機の動力を削減するため中間冷却器を持つ多段の圧縮機が 想定されている。この場合でも, 最終段の圧縮により希ガ スの温度は上昇する。すなわち, 圧縮機からのエネルギー の付与があることになる。しかし, 本装置で使用した圧縮 機では, 圧縮によるアルゴン温度の上昇はオイル冷却によっ て抑えられており, その出口温度は入口温度とほぼ等しく, 圧縮機からの熱の付与は極めて小さく，ここでは無視した。

Fig. 5 のアルゴンが得た熱量を見ると，アルゴンは再生 熱交換器から $25.3 \mathrm{~kW}$ の熱量を, またヒータで $222.5 \mathrm{~kW}$ の熱量を得ている。ここで, 注目すべきことは, アルゴン の加熱に再生熱交換器が寄与する割合が $10.2 \%$ と極めて小 さいことである。そこで，この原因を調べるため Fig. 5 の 右側の熱損失の棒グラフに着目すると, MHD 発電機とそ の下流の 6 本の排気ダクト (Fig. 2 参照) で $193 \mathrm{~kW}$ とい う大きな熱損失が生じていることが分かる。MHD 発電機 は超音速ノズル, 発電チャネル, ディフューザで構成され ているが，後で示すようにディフューザ部分での熱損失が 予想外に大きく，また排気用ダクトでの熱損失も大きかっ た。本来これらの流路もセラミックの熱絶縁構造を有する 設計をすべきであったが, 超伝導磁石のボアー径が小さい ことや，ディスク形発電機の使用から来る排気系の形状の 複雑さなどから, それができなかった。そこで大きな熱量 がこれらの部分で失われ, 再生熱交換器に流入するアルゴ ンの温度が低くなり, その結果, 再生熱交換器での熱交換 量が少なくなった。事実, Fig. 5 の右側の棒グラフを見る と, 再生熱交換器では $27.0 \mathrm{~kW}$ の僅かな熱量しか失われて 


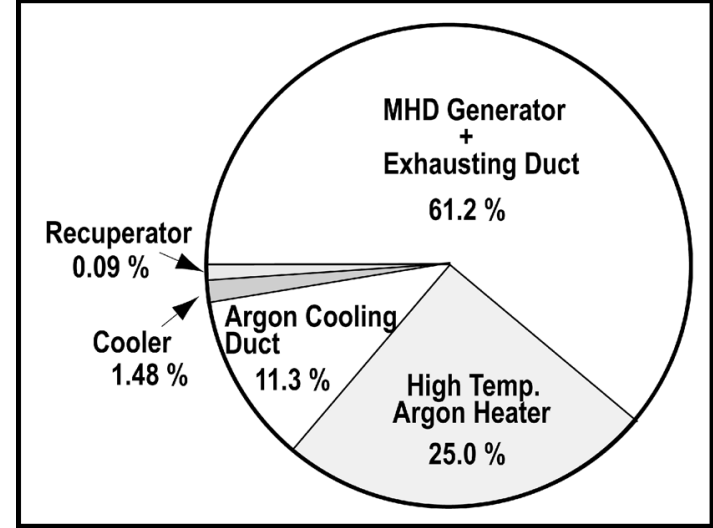

Fig. 6. Ratio of heat loss at each component measured in Run 12

いない。

このように，アルゴンの加熱に対する再生熱交換器の役 割は小さかったが，そこで失った $27.0 \mathrm{~kW}$ の熱量の $93.7 \%$ に相当する熱 $(=25.3 \mathrm{~kW})$ が回収されており，再生熱交換 器が比較的優れた熱交換性能を有していることが分かった。

次に，エネルギーバランスについて述べる。クローズド ループに投入されたエネルギーが，ループを構成する各機 器でどのように失われているかを知ることは将来の商用プ ラントを設計する際の貴重なデー夕を提供することになる。 ここで，ループへの熱入力について考える。本ループでの 熱入力は, 高温アルゴンヒータでの消費電力であり, Run 12

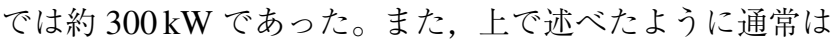
圧縮機の圧縮過程を通してループへの熱入力があるが，本 装置ではそれが極めて小さいためここでは無視して考える。 そこで，このヒータからの熱入力のみがループへの熱入力 となる。一方，本装置の各部分で失われた熱量については， それらを冷却している冷却水の流量と水温上昇から見積も ることができる。これによって見積もった冷却熱量の総和 は $309 \mathrm{~kW}$ となり，投入電力の $300 \mathrm{~kW}$ と完全には一致し なかった。この原因としては，冷却水温度の上昇が少ない 機器での水温の測定精度にあると考えられる。そこで，こ こでは冷却熱量の総和をループへの熱入力とし，これに対 する各部分の熱損失の割合を求め，その結果を Fig.6の円 グラフで示した。

Fig. 6 を見ると, 高温アルゴンヒータでの熱損失は $25 \%$ と 大きいことが分かる。この大きな熱損失は, ヒータ No.1 か ら No.3のそれぞれの管体の冷却，フランジ部の冷却，お よびヒータエレメントの電流リードの冷却に起因している。 本実験で観測されたこのヒータでの大きな熱損失は，将来 の商用プラントで用いる高温熱交換器を設計する際の重要 な指針を与えている。すなわち，それが非常に高い温度で 運転されるため, 冷却用の空気や水との温度差が大きくなる ことから，徹底した断熱対策が必要なことを示唆している。

Fig. 6 でのもう一つの特徴的な現象は，ディスク形 MHD 発電機とその下流の排気ダクトでの熱損失が $61.2 \%$ と極め

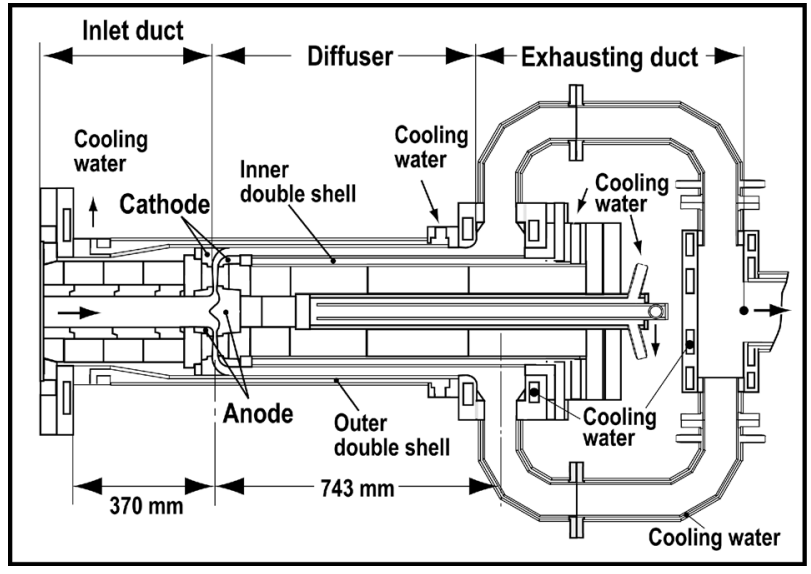

Fig. 7. Water cooling system for measurement of heat loss in diffuser and exhausting duct.

て大きいことである。したがって，この部分の断熱設計も 将来のプラントでは重要になる。さらに，排気ダクトの下 流のアルゴンクーリングダクトでの熱損失が $11.3 \%$ と大き いが，これは本装置固有の現象であり，金属（SUS）製の 再生熱交換器を使用したことにより，その入口温度を下げ る必要性からこのダクトが設置されている。一方，再生熱 交換器やクーラでの熱損失は小さかったが，これはこれら の機器の上流での大きな熱損失により温度の低下したアル ゴンが流入したためである。

〈3・3〉 ディフューザ部での大きな熱損失ここでは MHD 発電機のディフューザ部で観測された大きな熱損失に ついて述べるとともに，その原因について考察する。Fig.7 (拡大図は後の Fig. 14 参照) に示すように, ディスク型 MHD 発電機は，超音速ノズルの役割を兼ねたアノード，セラミッ クの絶縁壁，カソード，およびその下流の環状の流路で構成 されている。ここでディフューザを，カソード上流端から その下流の環状流路として定義する。Fig. 7 のよに，ディ フューザの壁は, 水冷構造を有する外側二重管と内側二重 管で構成されている。したがって，外側二重管と内側二重 管内を流れる冷却水の水量と温度を計測することにより， ディフーザ部分での熱損失を見積もることができる。また， ディフューザ下流の 6 本の排気ダクト部分も水冷構造であ り，同様にそこでの熱損失を見積もることができる。この ように見積もったディフューザでの熱損失は $136 \mathrm{~kW}$ と非 常に大きく，また排気ダクトでの熱損失も $52 \mathrm{~kW}$ と大き かった。

このように予想外の大きな熱損失が測定されたが，以下 にこの点について考察する。種々のプラント設計での熱損 失の取扱いでは, 通常, 円管内乱流熱伝達に対する熱伝達 率を用いた計算が行われている。そこで本研究でもこれに 従い，以下のような計算を行い，流れ方向の温度分布や各 部分での熱損失を見積もった。

計算には定常準一次元の質量保存式，運動量保存式，工 ネルギー式を用いたが，その詳細は文献(5)で記したので， ここではエネルギー式のみを記した。 


$$
\begin{aligned}
& \frac{\partial}{\partial x}\left\{\left(E_{s}+p\right) u A\right\}=-A Q_{\text {loss }} \\
& E_{s}=\rho\left(c_{v} T+1 / 2 u^{2}\right)
\end{aligned}
$$

ここで, $\rho$ はアルゴンの密度 $\left[\mathrm{kg} / \mathrm{m}^{3}\right], A$ は流路断面積 $\left[\mathrm{m}^{2}\right], c_{v}$ はアルゴンの定積比熱 $[\mathrm{J} /(\mathrm{kg} \cdot \mathrm{K})], u$ は流速 $[\mathrm{m} / \mathrm{s}]$, $p$ は静圧 $[\mathrm{Pa}], T$ はアルゴンの静温 $[\mathrm{K}], E_{s}$ は全エネル ギー $\left[\mathrm{J} / \mathrm{m}^{3}\right]$ を表す。さらに，(1)式の右辺 $Q_{\text {loss }}$ は，熱損失 $\left[\mathrm{J} /\left(\mathrm{m}^{3} \cdot \mathrm{s}\right)\right]$ を示し，以下のように亜音速領域では (2) 式，超 音速領域では (4) 式で表すことができる。

$$
\begin{aligned}
& Q_{\text {loss }}=A_{s} \alpha\left(T-T_{w}\right) \ldots \ldots \ldots \\
& \alpha=0.023 P_{r}^{0.4} R_{e}^{0.8} \frac{K_{g}}{d_{i}} \ldots \ldots \ldots \\
& Q_{\text {loss }}=A_{s} S_{t} \rho u c_{p}\left(T_{a w}-T_{w}\right) \\
& T_{a w}=\left(1+R_{f} \frac{(\kappa-1)}{2} M^{2}\right) T \\
& S_{t}=0.023 R_{e}^{-0.2} P_{r}^{-2 / 3} \ldots \ldots \ldots
\end{aligned}
$$

(2) 式に含まれる $A_{s}$ は濡れ縁長さを断面積で割ったもの $[1 / \mathrm{m}]$ を示し， $\alpha$ は熱伝達率 $\left[\mathrm{J} /\left(\mathrm{m}^{2} \cdot \mathrm{s} \cdot \mathrm{K}\right)\right], T_{w}$ は壁温 $[\mathrm{K}]$ を 表している。なお，本計算では亜音速領域での熱伝達率に は，十分に発達した円管内乱流に対する (3) 式を用いた。 (3) 式の $d_{i}$ は, 流路の内径 $[\mathrm{m}], \kappa_{g}$ はアルゴンの熱伝導率 $[\mathrm{J} /(\mathrm{m} \cdot \mathrm{s} \cdot \mathrm{K})]$ を表し， $P_{r}$ と $R_{e}$ はそれぞれプラントル数とレ イノルズ数である。超音速領域での熱損失を表す (4) 式で は， $S_{t}$ はスタントン数， $T_{a w}$ は断熱壁温度 $[\mathrm{K}]$ を表す。な お，断熱壁温度は超音速流れでの特徵的な温度であり，流れ のマッ八数 $M$ と静温 $T$, および比熱比 $\kappa$ から求められる。 また, $R_{f}$ は回復係数と呼ばれ，本計算ではその值を 0.88 と した。さらに，スタントン数は (5) 式のようにプラントル 数とレイノルズ数で表すことができる。

以上の式を用いて計算を行ったが, 計算領域としてはディ スク形発電機の入口から温度計測ポートを有する排気ダク ト出口までとした。また，実験装置に扔けるこの間の流路 の断面は，円形やディスク形，さらに環状であったり，ま た複数の円管が組合されたりしているが，計算では等価な 断面積を持つ円形流路として取扱った。また，デイスク形 チャネルの出口近くに垂直衝撃波が生ずると仮定し，それ より上流掞よび下流の流体諸量を Runge-Kutta-Gill 法を用 いて解いた。なお，計算では発電機入口から発電チャネル 出口までの長さは, 実際のものと異なるものを使用した。 これはディスク形状を一次元に置換えると, 短い距離で大 きな膨張となり，計算が進まなかったためである。

Fig. 8 には，(3) 式の円管内乱流に対する熱伝達率 $\alpha$ を 用いた時の流れの速度と静圧，およびアルゴンの全温をプ ロットした。上の図の流速を見ると，流れはノズルによっ て加速され, MHD チャネル出口の直前での流速は $1650 \mathrm{~m} / \mathrm{s}$ （マッハ数＝3.4）に達しているが，その下流での流れは衝 撃波によって亜音速に減速されている。一方，静圧はノズ ルでの加速により低下し，衝撃波によって回復している。 この時のアルゴンの全温の変化を見ると（Fig. 8 の下側の

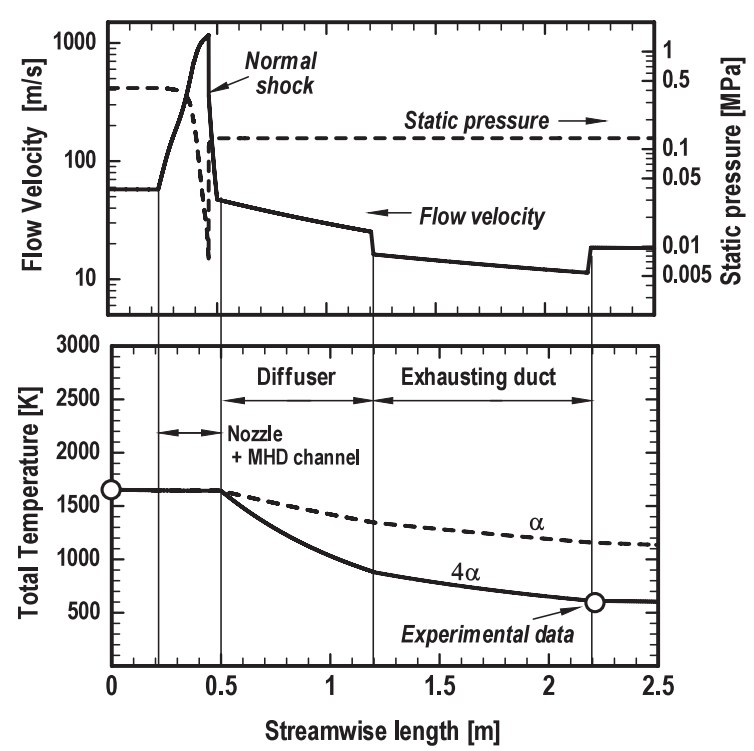

Fig. 8. Comparison of measured and calculated argon temperature for different heat transfer coefficient.

Table 1. Comparison of measured heat loss with numerically calculated one for different heat transfer coefficient.

\begin{tabular}{|l|c|c|c|}
\hline \multicolumn{2}{|c|}{ Location } & Diffuser & $\begin{array}{l}\text { Exhausting } \\
\text { duct }\end{array}$ \\
\hline \multicolumn{2}{|c|}{ Measured Heat Loss } & $136 \mathrm{~kW}$ & $52 \mathrm{~kW}$ \\
\hline \multirow{3}{*}{$\begin{array}{l}\text { Calculated } \\
\text { Heat Loss }\end{array}$} & $\begin{array}{l}\text { Heat transfer } \\
\text { coefficient }\end{array}$ & & \\
\cline { 2 - 4 } & $\alpha$ & $54 \mathrm{~kW}$ & $34 \mathrm{~kW}$ \\
\cline { 2 - 4 } & $4 \alpha$ & $138 \mathrm{~kW}$ & $50 \mathrm{~kW}$ \\
\hline
\end{tabular}

破線), ノズルからデイスク形流路においては全温度の低下 は少ないが，ディフューザでの全温の低下は著しく大きく なっている。また，排気ダクトでの全温の低下率は緩やか になっているが，流れ方向に全温の低下は続いている。な お，このような全温の大きな低下は，これらの流路が水冷 されていることによる。ここで，流れ方向の位置 $2.2 \mathrm{~m} て ゙$ の全温の実験值と計算值（破線）を比較すると，実験值が

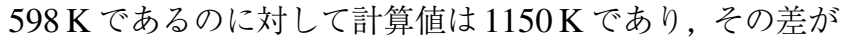
極めて大きくなっている。

そこで，この大きな差の原因を調べるため，(3) 式の熱伝 達率 $\alpha$ を 4 倍にした時の全温の計算結果を Fig. 8 の下側に 実線で示したが， $\alpha$ を 4 倍にした場合には，実験と計算の 全温は良く一致している。以上のように熱伝達率を 4 倍に 高めた計算では，実験值の温度を説明することができたが， 本当に熱伝達率が高まっていたかどうかについては，損失 熱量を計算と実験で比較する必要がある。そこで, Table 1 にはその比較を示した。Table 1 から, 熱伝達率 $\alpha$ を 4 倍 にした損失熱量の計算結果は実験とも良く一致しており, 実験では熱伝達率が大きく促進されていたことが示唆され る。次に，なぜこのように熱伝達が著しく促進されたかに ついて考える。これまでの研究では, 円管の内表面に粗さ やフィンなどの突起がある場合には，熱伝達が促進するこ とが知られているが(8), 本装置では内表面の滑らかな流路を 


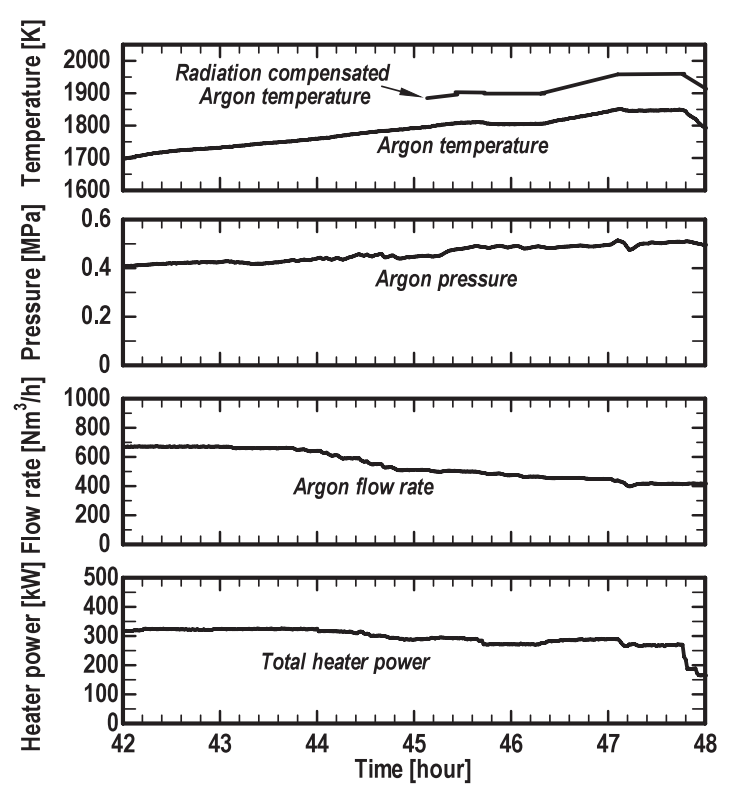

Fig. 9. Time traces of argon temperature, argon pressure, argon flow rate and total power input in Run 15.

使用しているためこのことは考元難い。しかし，実験で用 いたディフューザと排気ダクトは $90^{\circ} の$ 曲がりを持ってお り,また, 排気ダクトは縮小部, 拡大部などで構成されてい る。そこで，これらの流路形状が複雑な流れを生じさせて 熱伝達率が促進されたと推測される。事実, 本ディフュー ザ内流れの数值シミュレーションでは, 剥離や渦の存在が 指摘され扔り(9)，これらが原因と考えられる。

以上のように, 本実験によりディスク形 MHD 発電機用 のディフューザ部とその下流の排気ダクトでの熱損失につ いての情報が初めて得られた。ここで観測された大きな熱 損失は，流路にセラミックによる熱絶縁を施していないこ とによるが，流路形状によっては熱伝達率が著しく高まる という結果は普遍であり，この結果は将来のプラントにお けるディフューザ部と排気ダクトの設計では，極めて高い 断熱設計が必要であることを示唆している。

$\langle\mathbf{3 \cdot 4 \rangle}$ 高温アルゴンの連続循環とスロート断面積の変 化ここでは, 本実験で得られたアルゴンの最高温度と その連続循環，掞よびディスク形発電機内のスロート断面 積の時間変化について述べる。Fig. 9 には, Run 15 でのア ルゴン温度と圧力, アルゴン流量, 高温アルゴンヒータヘ の全投入電力の時間変化を示した。この図の横軸は, 圧縮 機の起動後の 42 時間からその停止直前までの 48 時間を 示している。アルゴン流量とヒータへの投入電力に着目す ると，本実験ではそれらを 43 時間後から徐々に減少させ て運転していることが分かる。これは，後で述べるように ディスク形流路のスロート高さが時間的に減少し，アルゴ ン圧力が異常に高くなるのを抑えるためである。次にアル ゴン温度に着目する。ここで，アルゴン温度はタングステ ンータングステンレニウムの熱電対を用いて計測しており, $1700 \mathrm{~K}$ を大きく超えるような温度では熱電対からの輻射が 無視できなく，輻射を考慮した温度補正が必要になる。そ

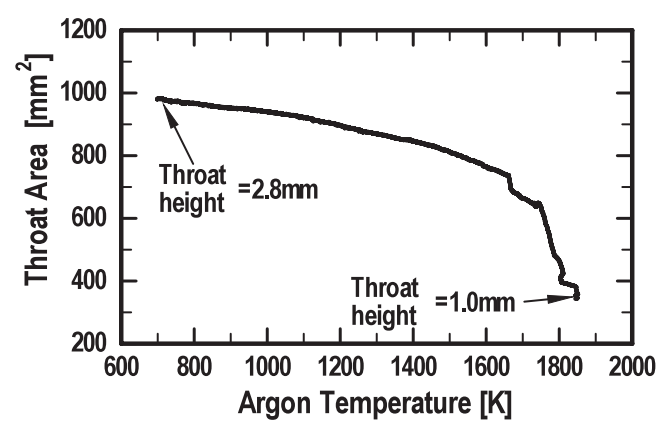

Fig. 10. Change of throat area vs. argon temperature without radiation compensation in Run 15.

こで, Fig.9のアルゴン温度としては, 熱電対が指示する 温度と輻射補正した温度を示した。この図より，45.4 時間 から 47.8 時間まで, 輻射補正したアルゴン温度は $1910 \mathrm{~K}$ から $1970 \mathrm{~K}$ を示しており，本クローズドループを $1900 \mathrm{~K}$ 以上の高い温度で約 2 時間 20 分連続的に運転できたこと が分かる。

次に，スロート断面積の時間変化について述べる。超音 速ノズルを有するクローズドループでは，ループ内を循環 するアルゴンの質量流量 $\dot{m}$ はスロートの断面積 $A^{*}$ と密接 に関係しており，以下のような式で表わされる ${ }^{(10)}$ 。

$$
\dot{m}=\sqrt{\frac{\kappa}{R}\left(\frac{2}{\kappa+1}\right)^{\frac{\kappa+1}{k-1}} \frac{p_{0}}{\sqrt{T_{0}}}} A^{*}
$$

ここで, $K$ とRはそれぞれアルゴンの比熱比と気体定数 を表し， $p_{0}$ と $T_{0}$ はそれぞれスロートより上流のアルゴン の全圧と全温を表す。(6) 式のように, 質量流量はスロート 断面積 $A^{*}$ で決定され, 質量流量 $\dot{m}$ を一定に保ってループ を運転した場合には，熱澎張によるスロート断面積の減少 に伴い全圧 $p_{0}$ が上昇する。過度な全圧の増加はループの 安全性を損なうことになり避けなければならない。一般的 に, ディスク形発電機のスロート高さは低く,ループの運 転にとってはスロート高さの時間変化の情報は重要である。 本実験では, ループの運転中の質量流量 $\dot{m}$, 全圧 $p_{0}$, 全温 $T_{0}$ を常時モニターしているが，これらのデータと (6) 式か らスロート断面積 $A^{*}$ を求めた。その結果を Fig. 10 に示し た。な扮，この図では輻射補正していないアルゴン温度に 対してスロート断面積の変化をプロットした。この図より, スロート断面積はアルゴン温度が高くなるにつれ徐々に減 少し, $1630 \mathrm{~K}$ からは急激に減少して最終的には $344 \mathrm{~mm}^{2}$ となっている。また, この時のスロート高さは $1.0 \mathrm{~mm}$ と

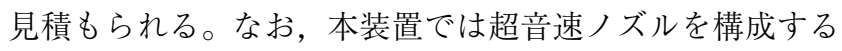
上下のモリブデン製のアノードを，直径 $6 \mathrm{~mm}$ のタングス テンロッド 6 本で支持しているが，ノズルより上流の入口 流路を構成するセラミックの熱膨張により, タングステン ロッド自身が塑性変形し，それによりスロート高さが減少 したと考えられる。

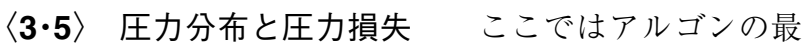
高温度が得られた Run 15 での圧力分布と圧力損失につい 


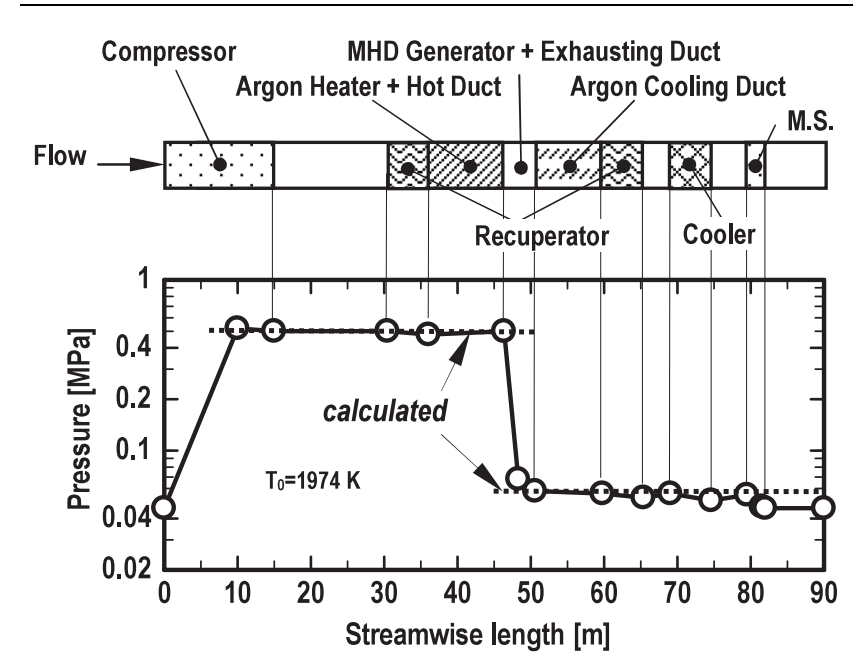

Fig. 11. Static pressure distribution under the highest argon temperature in Run 15.

て述べる。Fig. 11 には，流れ方向の静圧分布の実験值と， 次節で述べる計算から求めた全圧を示した。実験での圧力 に着目すると，圧縮機出口からディスク形発電機入口まで の圧力損失は非常に小さく，また，アルゴンクーリングダ クト, 再生熱交換器, クーラでの圧力損失も小さいことが 分かる。しかし，ディスク形発電機と排気ダクトでの圧力 損失は非常に大きくなっている。ここで発電機入口より上 流，および排気ダクトより下流での静圧は，アルゴンの流 速が低いために全圧にほぼ等しいことを考慮すると，発電 機入口の全圧は $0.50 \mathrm{MPa}$ であり, 排気ダクト出口での全 圧は $0.058 \mathrm{MPa}$ と見積もられる。したがって, 約 $0.44 \mathrm{MPa}$ の全圧損失が生じている。このように大きな全圧損失は, ディスク形発電機内で衝撃波が生じ，それが壁面に形成さ れる速度境界層と複雑に干渉する，いわゆる擬似衝撃波の 発生や，〈3·3 節で述べた大きな熱損失の原因となってい る複雑な流机に起因していると考えられる。

なお，このように大きな圧力損失を伴う条件で本ループ を運転したのは，ディスク形発電機内での超音速領域を 極力下流まで広げるためであった。しかし，圧力比 8.62 $(=0.50 \mathrm{MPa} / 0.058 \mathrm{MPa})$ でも，上で述べたスロート断面積 の縮小により実質的な発電機の断面積比（=発電機出口断 面積/スロート断面積）が 11 程度と大きくなり，ノズル出 口のすぐ下流で衝撃波が生じていると推察される。

〈3.6〉 超音速クローズドループの圧力比 前節では圧 力損失について述べたが，この圧力損失はループに与える圧 力比と関係している。すなわち，ループの圧力比に見合う ように流れ場が決まり，圧力損失も決まる。ここではルー プの圧力比がどのように決まるかについて検討する。その ため本クローズドループを簡略化し， Fig. 12 に示すループ を考える。ここで，スロートを境としてその上流の圧縮機 出口までを高圧部分とし，スロートから下流の圧縮機入口 までを低圧部分とする。また，高圧部分での全圧は等しく， 同様に低圧部分での全圧も等しいと仮定する。次に，各部 分の体積を $V$ 抒よびその添え字で表し，さらに各記号を以

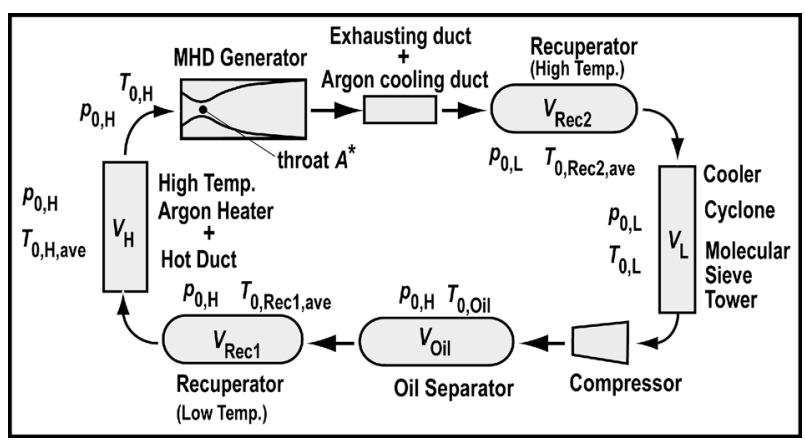

Fig. 12. Schematic diagram of closed loop used in calculation of total pressure $\left(V=\right.$ volume, $p_{0}=$ total pressure, $T_{0}=$ total temperature $)$.

下のように定義する。

\section{$p_{0, H}:$ 高圧部分の全圧}

$p_{0, L}:$ 低圧部分の全圧

$T_{0, H}:$ ホットダクト出口からスロートまでの全温

$T_{0, H, a v e}$ : ヒータ入口からホットダクト出口までの 全温の平均值

$T_{0, R e c 1, a v e}$ : 再生熱交換器（低温側）での全温の平 均值

$T_{0, \text { Oil }}:$ オイルセパレータでの全温

$T_{0, R e c 2, a v e}$ : 再生熱交換器（高温側）での全温の平 均值

$T_{0, L}:$ クーラ, サイクロン, モレキュラーシーブ塔 での全温

ここで, Fig. 12 のスロートを通過するアルゴンの質量流 量 $\dot{m}$ は，前掲の (6) 式で表すことができるが，上で定義し た全圧と全温を用いて書き直すと次のようになる。

$$
\dot{m}=\sqrt{\frac{\kappa}{R}\left(\frac{2}{\kappa+1}\right)^{(\kappa+1) /(\kappa-1)}} \frac{p_{0, H}}{\sqrt{T_{0, H}}} A^{*}
$$

次に，(7) 式を用いるとスロートより上流の高圧部分の全圧 $p_{0, H}$ は，次のように表わされる。

$$
p_{0, H}=\frac{1}{\text { const } .} \times \frac{\sqrt{T_{0, H}}}{A^{*}} \times \dot{m} .
$$

この式は，スロートより上流の高圧部分の全圧 $p_{0, H}$ が，質 量流量 $\dot{m}$ が一定でスロート断面積に変化がない場合には, ホットダクト出口での全温 $T_{0, H}$ で決定されることを示して いる。事実, Fig. 3 に戻りスロートより上流のホットダク トで計測したアルゴンの圧力の時間変化を見ると，アルゴ ンの流量が一定となっている時刻では，それがアルゴン温 度と共に変化している様子が見て取れる。

次に，低圧部分の全圧について考える。このため，アル ゴンの密度を $\rho$ とし, 各部分での密度 $\rho$ をその添え字で表 わすと, ループ内の全質量 $M_{t}$ は各部分の体積を用いて以 下のように表される。 


$$
\begin{aligned}
M_{t}= & \rho_{H} V_{\text {Oil }}+\rho_{H} V_{\operatorname{Rec} 1}+\rho_{H} V_{H}+\rho_{L} V_{\operatorname{Rec} 2}+\rho_{L} V_{L} \\
= & \frac{p_{0, H}}{R}\left(\frac{V_{\text {Oil }}}{T_{0, \text { oll }}}+\frac{V_{\operatorname{Rec} 1}}{T_{0, \operatorname{Rec} 1, \text { ave }}}+\frac{V_{H}}{T_{0, H}}\right) \\
& +\frac{p_{0, L}}{R}\left(\frac{V_{\operatorname{Rec} 2}}{T_{0, \operatorname{Rec} 2, \text { ave }}}+\frac{V_{L}}{T_{0, L}}\right) \ldots \ldots \ldots \ldots \ldots \ldots \ldots
\end{aligned}
$$

なお，ディスク形発電機や排気ダクト，さらにアルゴンクー リングダクトの体積は小さいため無視した。この式をさら に変形すると，低圧部分の圧力 $p_{0, L}$ は次式のようになる。

$$
p_{0, L}=\frac{R M_{t}-p_{0, H}\left(\frac{V_{\text {Oil }}}{T_{0, \text { Oil }}}+\frac{V_{\operatorname{Rec} 1}}{T_{0, \operatorname{Rec} 1, a v e}}+\frac{V_{H}}{T_{0, H}}\right)}{\left(\frac{V_{\operatorname{Rec} 2}}{T_{0, \operatorname{Rec} 2, \text { ave }}}+\frac{V_{L}}{T_{0, L}}\right)}
$$

この式より, 低圧部分の圧力 $p_{0, L}$ は, ループ内の全質量 $M_{t}$ が与えられ，高圧部分の全圧 $p_{0, H}$ が決まれば，各部分の全 温とその体積で自動的に決定されることを示している。

以上のように, 高圧部分の全圧 $p_{0, H}$ は, 質量流量 $\dot{m}$ が与 えられた時アルゴンの全温 $T_{0, H}$ で決まること，また，ルー プ内の全質量 $M_{t}$ が与えられた場合には，低圧部分の全圧 $p_{0, L}$ は，高圧部分の全圧 $p_{0, L}$ で決まることを述べたが，こ れを検証するため実験結果と比較する。ここで Fig. 11 に戻 ると, この図では本計算で求めた全圧のスロートから上流 と下流での值をそれぞれ破線で示した。眓から明らかなよ うに, 実験結果と本計算結果とはほほ一致している。

また (10) 式より，スロートより下流部でアルゴンを排気 して全質量 $M_{t}$ を減らした場合には， $p_{0, L}$ が下がることに なり，圧力比 $p_{0, H} / p_{0, L}$ を大きくできることが分かる。ルー プ内の流れは，このように決められた圧力比の下で振舞う ことになるが，本実験では大きな圧力損失により圧力比を 8.62 まで高めざるを得なかった。

$\langle\mathbf{3} \cdot \mathbf{7}\rangle$ 発電実験の結果 Fig.9で示したように, Run 15 での時刻 47.1 時間では，アルゴン温度を $1974 \mathrm{~K}$ まで高め ることができた。さらに，発電機の性能を劣化させる原因 となるアルゴン中の水分については， $40 \mathrm{ppm}$ 以下に，また 酸素や窒素についても，20 ppm と $150 \mathrm{ppm}$ 以下にそれぞ れ抑えることができた。このように，スロート断面積の熱 膨張による減少を除けば発電実験を行う条件が整った。そ こで，Fig. 14 に示す負荷結線と実験条件で発電を試みた。 その結果を Fig. 13 に示した。

Fig. 13 のシード率の時間変化を見ると, シード注入バル ブを開にした 2-3 秒後にシードが注入されていること，ま たバルブの閉の後もしばらくシードがアルゴン中に残存し ていることも分かる。なお， シード率に時間的に大きな摇 らぎが見られるが，これは吸収率の測定に用いたレーザダ イオードのノイズの影響による。出力電圧であるホール電 圧を見ると，それはシード注入と同時に現れ，約 $-7 \mathrm{~V}$ と なっている。なお, ホール電圧が負になっているのは, カ ソードを接地しているためである。このホール電圧は, 負 荷抵抗を $1 \mathrm{k} \Omega, 3 \Omega, 1 \mathrm{k} \Omega, 2 \Omega, 1 \mathrm{k} \Omega$ と順次切換えると

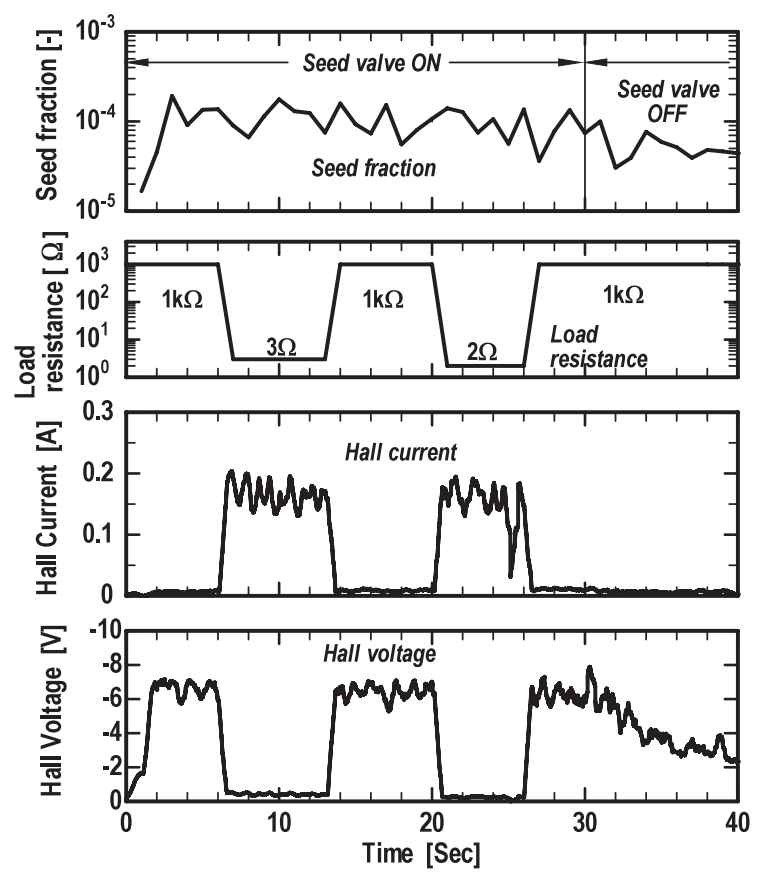

Fig. 13. Time traces of seed fraction, load resistance, Hall current and Hall voltage in Run 15.

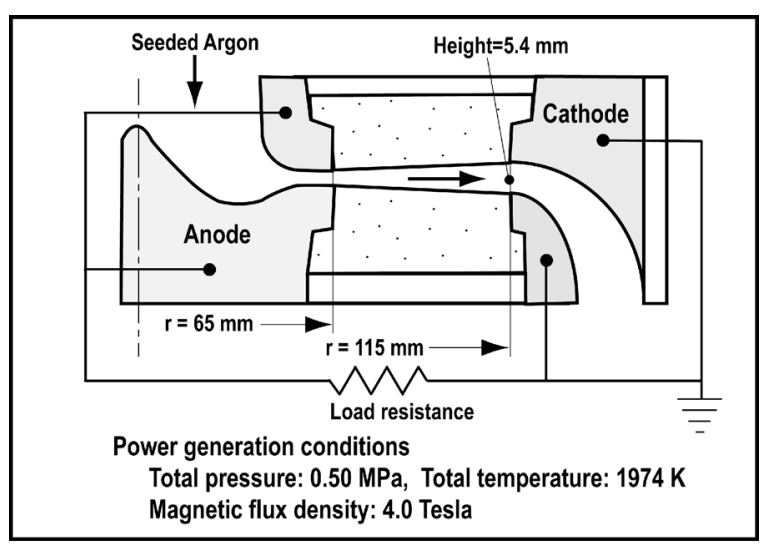

Fig. 14. Diagram of load connection and experimental conditions of power generation in Run 15 .

ステップ状に変化し，またホール電流もステップ状に変化 している。このように負荷切換えによる発電機からの出力 の変化が見られ，超音速クローズドループを用いた初めて の発電が確認できた。しかし，何回か同様の実験を繰返し たが, ホール電圧抢よび電流とも小さく, 出力の最大值は $0.7 \mathrm{~W}$ から $1 \mathrm{~W}$ という極めて小さいものであった。この原 因としては, 先に述べたスロート断面積の著しい減少によ り, 発電機の断面積比が初期設定の 4.0 から 11 程度まで大 きくなったことによると考えられる。断面積比が大きい場 合には, 発電チャネル内の一部分でしか超音速流れが実現 せず，起電力が小さくなる。この他に，Fig. 13 に示したよ うにシード率も $1 \times 10^{-4}$ 程度と低く, 十分な電気伝導度が 得られなかったことにもよると考えられる。 


\section{4. まとめ}

本研究では, 超音速クローズドループを研究対象として, その作動気体であるアルゴンの加熱特性，ループ内のアル ゴンの温度分布，エネルギーバランス，熱損失，圧力分布な どについて実験的に調べるとともに，ループの圧力比が決 まるメカニズムを明らかにした。また，超音速クローズド ループで初めて試みた発電実験の結果について述べた。以 下にその結果をまとめた。

（1）超音速クローズドループで，アルゴン温度を $1900 \mathrm{~K}$ 以上に加熱した状態で，連続 2 時間 20 分程度の循環運転 を行うことができた。

（2）アルゴンが授受した熱量についてのエネルギーバ ランスを明らかにした。その結果，再生熱交換器でのエネ ルギー効率は高かったが, 積極的な断熱を施さなかったディ フューザとその下流の排気ダクトで大きな熱損失が生じて いることが明らかになった。

（3）ディスク形発電機を用いた場合には，ディフュー ザと排気ダクトの形状が複雑になり，通常用いられる管内 の乱流熱伝達率では説明できない大きな熱伝達率の存在が 示唆された。このことは, 将来のプラント設計において, こ れらの機器の形状設計や断熱設計において注意を要するこ とを示唆している。

（4）ディスク形発電機を組込んだクローズドループで は，ノズルのスロート断面積が小さいため, 材料の熱膨張に よるスロート断面積の減少に注意を要することが示された。

（５）超音速クローズドループでは，スロートより上流 の圧縮機出口までの全圧は，質量流量と全温で決定される。 また上流の全圧が決まれば，下流の圧縮機入口までの全圧 は，ループ内の全質量で決まることが明らかになった。

（6）超音速クローズドループで初めての発電を試み, 負 荷抵抗值とホール電圧には良い相関がみられた。しかし， 発電出力は極めて小さく，スロート断面積の減少により発 電機内の流れが大きな出力を得るには十分でなかったこと が示唆された。

最後に，本研究は日本学術振興会科学研究費補助金基盤 研究 $(S)$ （課題番号：15106005）の研究助成を受けて実施 したことを付記する。

(平成 20 年 4 月 9 日受付，平成 20 年 7 月 8 日再受付)

\section{文献}

(1) T. Murakami, Y. Okuno, and H. Yamasaki: "Experiments of the Improvement in the Performance of a Disk CCMHD Generator", IEEJ Trans. PE, Vol.124-B, No.11, pp.1394-1399 (2003-11) (in Japanese) 村上朝之・奥野喜裕・山岬裕之：「ディスク形 CCMHD 発電機の高 性能化実験」,電学論 B, 123, 11, pp.1394-1399 (2003-11)

(2) Y. Okuno, K. Yoshikawa, T. Okamura, H. Yamasaki, S. Kabashima, and S. Shioda: "Proposal of a Highly Efficient CCMHD Single Power Generation System", T. IEE Japan, Vol.118-B, No.12, pp.1457-1462 (1998-12) (in Japanese)

奥野喜裕·吉川邦夫·岡村哲至・山岬裕之·椛島成治·塩田 進:「高効 率 CCMHD 単独発電システムの提案」, 電学論 $\mathrm{B}, \mathbf{1 1 8}, 12, \mathrm{pp} .1457-1462$
(1998-12)

(3) T. Bohn, K. Grawtsch, Ch. Hozapfel, G. kolb, P. Komarek, H. Lang, G. Noack, and P. Schabel: "Construction and Test of ARGAS-II", 11th Symposium on Engineering Aspects of MHD, pp.104-108 (1970)

(4) R.J. Sovie: "Closed Cycle MHD Power Generation Experiments Using a Helium-Cesium", 15th Symposium on Engineering Aspects of MHD, pp.VI.1.1-1.6 (1976)

(5) H. Yamasaki, L.V. Uehara, and Y. Okuno: "Performance Analysis of Closed Loop in CCMHD Single Power Generation System", T. IEE Japan, Vol.122B, No.3, pp.449-459 (2002-3) (in Japanese)

山岬裕之・ルイスービラーウエハラ・奥野喜裕：「CCMHD 単独発電 システムにおけるクローズドループの性能解析」, 電学論 $\mathrm{B}, \mathbf{1 2 2}, 3$, pp.449-459 (2002-3)

(6) H. Takana, Y. Okuno, and H. Yamasaki: "Transient Response of Closed Loop MHD Experimental Facility”, IEEJ Trans. PE, Vol.124, No.11, pp.1343-1348 (2004-11) (in Japanese)

高奈秀匡・奥野喜裕・山岬裕之：「クローズドループ MHD 発電装置 の過渡応答特性」, 電学論 B, 124, 11, pp.1343-1348 (2004-11)

( 7 ) Y. Okuno, T. Murakami, and H. Yamasaki: "Closed Loop Experimental Facility for CCMHD Electrical Power Generation, 1 System and Operation", 15th International Conference on MHD Energy Conversion, CD, pp.29-35 (2005)

(8) JSME Data Book: Heat Transfer, 4th Edition, pp.190-194, Japan Society of Mechanical Engineers (2001) (in Japanese) 伝熱工学資料, 改訂第 4 版, pp.190-194, 日本機械学会 (2001)

(9) A. Liberati, T. Murakami, Y. Okuno, and H. Yamasaki: "Numerical Simulation on Performance of Disk MHD Generator in the Closed-Loop Experimental Facility", IEEE Trans. Plasma Science, Vol.34, No.6, pp.2669-2677 (2006)

(10) T. Ikui and K. Matsui: Dynamics of Compressible Fluid, 1st Edition, p.41, Rikougakusya (1989) (in Japanese)

生井武文・松尾一泰 : 圧縮性流体の力学, 第 1 版, p.41, 理工学社 (1989)

山 岬 裕 之（正員） 1944 年 4 月 2 日生。1967 年 3 月新潟

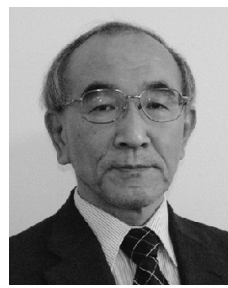
大学工学部機械工学科卒業。1969 年 3 月東京工 業大学大学院理工学研究科修士課程修了。同年 4 月同大学工学部助手, 1980 年 4 月同大学大学院 総合理工学研究科助教授, 1990 年 4 月同大学原 子炉工学研究所教授, 1996 年 10 月同大学大学院 総合理工学研究科に異動, 現在に至る。MHD 発 電，電磁流体力学の応用に関する研究に従事。工

学博士。

村上朝之（正員） 1970 年 1 月 28 日生。1993 年 3 月東京

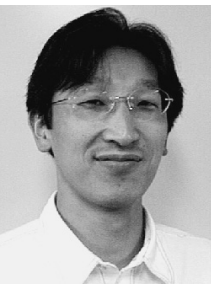
理科大学理工学部電気工学科卒業。1998 年 3 月 年東京工業大学総合理工学研究科創造エネルギー 専攻博士課程修了。同年 4 月同大学原子炬工学研 究所，1999 年 4 月東北大学大学院工学研究科を 経て, 2000 年 4 月東京工業大学総合理工学研究 科助教，現在に至る。博士 (工学)。電気学会, プ ラズマ・核融合学会, 低温工学協会, IEEE 会員。

奥 野 喜 裕 (正員) 1959 年 5 月 4 日生。1982 年 3 月九州工

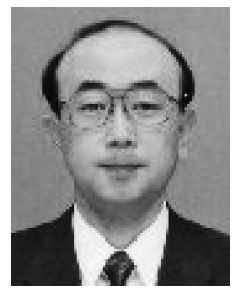
業大学電気工学科卒業。1987 年 3 月東京工業大 学エネルギー科学専攻博士課程修了。同年 6 月長 崎大学助手。1 1988 年 4 月佐賀大学講師，1989 年 4 月同助教授。1994 年 4 月東京工業大学大学院 助教授, 2000 年 4 月東京工業大学大学院教授，現 在に至る。主として, 電磁流体力学, プラズマ工 学に関する研究に従事。工学博士。 